\title{
Oral health effects of botulinum toxin treatment for drooling: a systematic review
}

\author{
Luisa Barreto Costa Corrêa ${ }^{1,2}$, Maurício Bartelle Basso ${ }^{3}$, Bernardo Sousa-Pinto ${ }^{4}$, Soraya Coelho Leal ${ }^{5}$
}

${ }^{1}$ DDS, MSc. MEDCIDS. Department of Community Medicine, Information and Decision Sciences, Faculty of Medicine, University of Porto, Portugal

${ }^{2}$ State Health Secretariat of Federal District, Brasília, Distrito Federal, Brazil

${ }^{3}$ DDS, MSc. State Health Secretariat of Federal District, Brasília, Distrito Federal, Brazil

${ }^{4} \mathrm{MD}$, PhD. CINTESIS - Center for Health Technology and Services Research, University of Porto, Portugal

${ }^{5} \mathrm{DDS}, \mathrm{PhD}$. Faculty of Health Science, Department of Dentistry, University of Brasilia, Brazil

Correspondence:

MEDCIDS - Department of Community Medicine

Information and Decision Sciences

Faculty of Medicine, University of Porto

Rua Dr. Plácido da Costa, 4200-450, Porto, Portugal

luisabcc@gmail.com

Received: $19 / 06 / 2020$

Accepted: 30/11/2020

Corrêa LBC, Basso MB, Sousa-Pinto B, Coelho Leal S. Oral health effects of botulinum toxin treatment for drooling: a systematic review. Med Oral Patol Oral Cir Bucal. 2021 Mar 1;26 (2):e172-80.

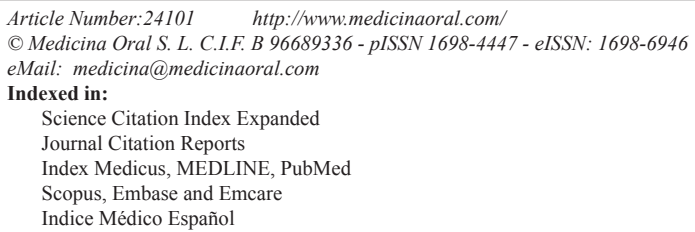

\begin{abstract}
Background: Drooling is a major morbidity in several neurological diseases. Intraglandular botulinum neurotoxin (BoNT) injections have been used to manage this condition. However, by decreasing salivary flow, BoNT injections may result in an increased risk of caries and other oral adverse effects. In this study, we aimed to assess whether, in patients with drooling, intraglandular BoNT injections are associated with increased dental caries development, modifications on salivary composition (oral $\mathrm{pH}$, buffering capacity and osmolality) and cariogenic bacterial load. Material and Methods: We performed a systematic review, searching PubMed, CENTRAL, Web of Science, and Scopus for all experimental and observational studies reporting on adverse effects of intraglandular BoNT injections in patients with drooling. Primary study selection, quality assessment, and data extraction were independently performed by two researchers. No studies were excluded based on their language, publication status or date of publication. Studies' quality was based on revised Cochrane Risk of Bias tools. Meta-analysis was not performed.

Results: We retrieved 1025 studies, of which 5 were included. Two studies were two randomized controlled trials and three quasi-experimental studies. None of the included studies found BoNT injections to be associated with dental caries development or with significant reductions in oral $\mathrm{pH}$. One of the included primary studies even observed an increase in salivary buffer capacity. One study found an increase in Lactobacilli counts. As for the risk of bias, two studies were classified as having a critical risk, two as high risk and one as having some concerns. Conclusions: Currently, there is no evidence that, in patients with drooling, BoNT injections associate with increased risk of dental caries or disturbances in oral $\mathrm{pH}$ or salivary buffering capacity. However, the included primary studies had important limitations and differences in their methodologies.
\end{abstract}

Key words: Neurological diseases, drooling, sialorrhea, botulinum toxin, oral health, caries, saliva. 


\section{Introduction}

Drooling is a major morbidity in several neurological diseases (1). It usually results in maceration and infections of the peri-oral skin (1-4), dysfunctional eating (4), disturbed speech $(1,2,4,5)$, halitosis (4), aspirationrelated pulmonary complications (1-5), and stigmatization or social isolation $(1,2)$. Also, drooling often poses hygienic problems for caregivers because of constant soiling of clothes (1) and other objects (4). This prompts the need for effective and safe approaches to manage drooling (3). One therapeutic approach consists of injecting botulinum toxin (BoNT) into the salivary glands $(2,3,6)$. The literature $(2,7,8)$ has shown that BoNT injections are effective in the management of sialorrhea, with most patients reporting a transient improvement in their symptoms $(9,10)$.

Botulinum toxin acts by transiently blocking parasympathetic and postganglionic sympathetic acetylcholine release (11-13). In general, parasympathetic stimuli increase the output of water and electrolytes, whereas, when sympathetic stimuli dominate, there is an enhancement of protein synthesis and secretion from acinar cells $(14,15)$. Therefore, by interfering with autonomic innervation of salivary glands and, thus, prompting a decrease in salivary flow, BoNT can affect the defense mechanism of saliva and may be associated with changes in the salivary composition $(16,17)$ and increased risk of dental caries development $(1,2)$. However, evidence regarding intraglandular BoNT adverse events in oral health has not yet been systematically assessed.

Therefore, the objective of this study is to perform a systematic review of experimental and observational studies in order to assess whether, in patients with drooling, BoNT injections into the salivary glands associate with increased risk of dental caries development, modifications on salivary composition such as salivary $\mathrm{pH}$ value, buffering capacity of saliva and osmolality - and modifications on counts of cariogenic bacteria, including salivary counts of Streptococcus mutans (S.mutans) and Lactobacilli. In addition, this study aimed to assess the methodological quality of existing evidence on the safety of intraglandular BoNT for treatment of drooling, discuss the main limitations of the current evidence, as well as to produce methodological recommendations for future studies on this field.

\section{Material and Methods}

This systematic review was conducted in accordance with the "Preferred Reporting Items for Systematic Reviews and Meta-Analysis (PRISMA) statement (18) and has been registered on PROSPERO database (Registration CRD42019137023).

We included experimental and observational studies in which BoNT injections into salivary glands were used to treat drooling irrespective of patients' underlying disease. We included studies that reported on adverse events of BoNT on oral health, particularly regarding (i) caries development; (ii) modifications of salivary composition (salivary $\mathrm{pH}$ value, buffering capacity of saliva, and hydration level - osmolality); and (iii) modification of salivary counts of cariogenic bacteria, especially Streptococcus mutans and Lactobacilli. No studies were excluded based on their language, publication status or date of publication.

We searched PubMed, CENTRAL, Web of Science and Scopus in May 2019 to identify relevant primary studies. Manual searching was also performed to collect data reported in books and conference abstracts, as well as by searching references of included primary studies. The search queries can be found on Supplement1 (http:// www.medicinaoral.com/medoralfree 01/aop/24101_ supplement1.pdf). After removing duplicates, two reviewers (LC and MB) were independently involved in selecting the studies, firstly by title and abstract reading, and then by full-text reading.

Data were independently extracted from primary studies by two researchers, using specifically designed forms. Extracted data from primary studies included the number of patients and their sex and age distribution, underlying/previous diseases, BoNT type, administration dosage of BoNT, number of botulinum toxin sessions, administration dosage of BoNT, site of application of BoNT, follow-up time, salivary $\mathrm{pH}$ value, buffering capacity of saliva, osmolality, and salivary counts of the cariogenic bacteria (especially S. mutans and Lactobacilli). Authors of the included primary studies were contacted for providing eventual missing data. The quality of primary studies was independently assessed by two authors based on the Revised Cochrane risk-of-bias tool for randomized trials (19) (RoB 2.0 tool) and Risk of Bias in Non-randomized Studies - Interventions (ROBINS-I) (20) questionnaire for nonrandomized studies. Any disagreement was solved by discussing with a third researcher.

Results were presented using descriptive statistics. We performed the Chi-square test to assess the statistical significance of the incidence of carious lesions in one of the included primary studies (2). Meta-analysis was not performed due to the small number of included studies and the relevant methodological and clinical differences between them.

\section{Results}

Fig. 1 illustrates the study selection process. We retrieved a total of 1025 records through database searching, and nine through manual search. After removal of duplicates $(\mathrm{n}=254), 780$ studies were screened by title and abstract reading. 
Fig. 1: PRISMA flow diagram.
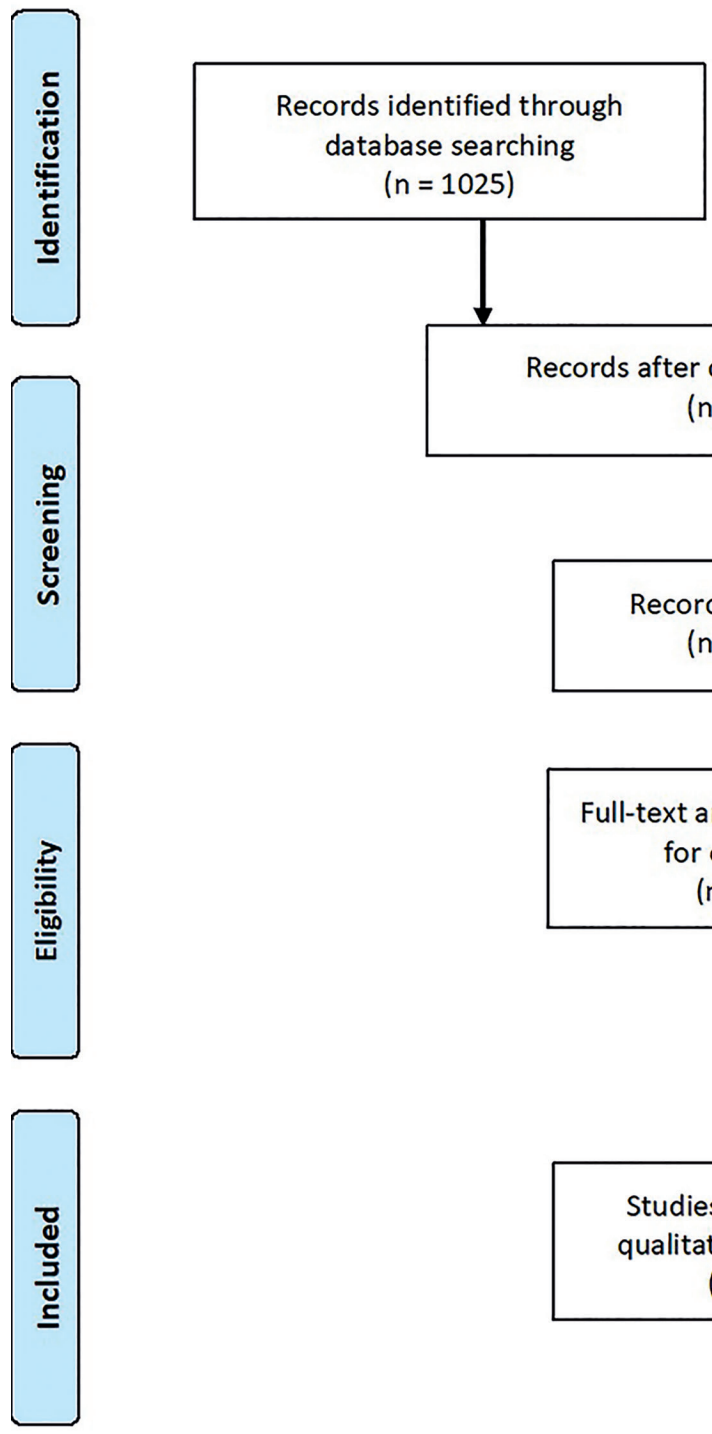

$(n=1025)$
Additional records identified through other sources $(n=9)$

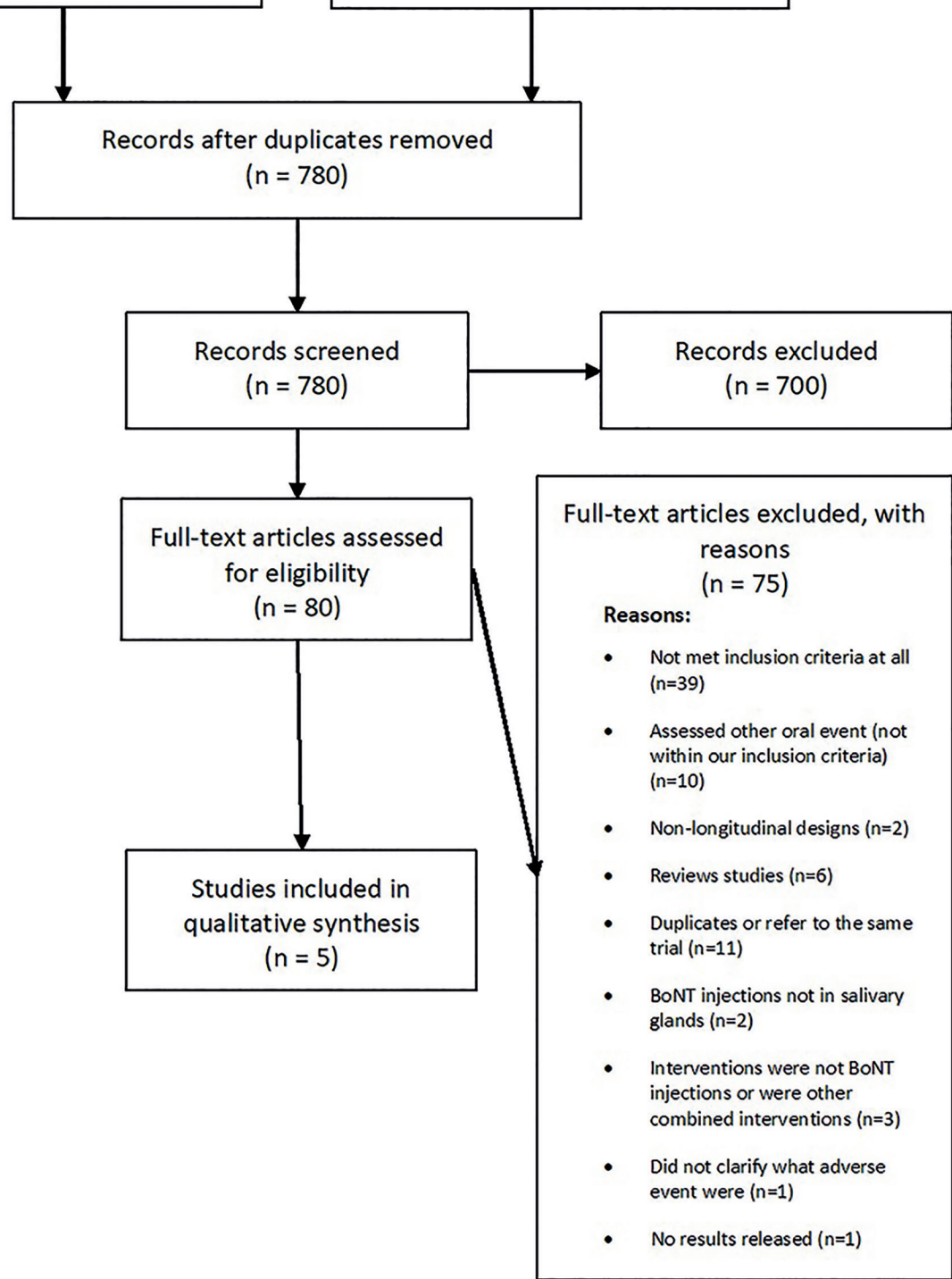

Eighty articles were fully read, out of which 5 primary studies were selected and included in this systematic review $(2,16,21-23)$ - of note, among the included studies, information about one of the randomized controlled trials (RCT) (2) was available in conference abstracts, on a poster, on an article supplement, and at clinicaltrials. gov under the identifier NCT01994109.

Two studies included in this review were RCTs $(2,21)$ and three were quasi-experimental studies $(16,22,23)$.
The characteristics of included primary studies (along with demographic and clinical characteristics of participants) are presented in Table 1. Out of the five included primary studies, salivary buffering capacity $(22,23)$ was assessed by two; oral $\mathrm{pH}$ and $\mathrm{S}$. mutans and $\mathrm{Lac}$ tobacilli salivary counts were assessed by three (21-23), and carious lesions were assessed by two $(2,16)$. Interventions and outcomes of included studies are summarized in Table 2. 
Table 1: Characteristics, demographics and summary of included studies.

\begin{tabular}{|c|c|c|c|c|c|c|}
\hline Author & Country & Study Design & $\begin{array}{c}\text { Number of } \\
\text { participants }\end{array}$ & Underlying Disease (\%) & $\begin{array}{l}\text { Age group } \\
\text { [mean years } \\
\text { old (range)] }\end{array}$ & $\begin{array}{c}\text { Gender } \\
\text { (male/fe- } \\
\text { male) }\end{array}$ \\
\hline $\begin{array}{l}\text { Stuart Isaa- } \\
\text { cson et al. } \\
\quad(2020)\end{array}$ & $\begin{array}{l}\text { Multicenter } \\
\text { (United States, } \\
\text { Russia and } \\
\text { Ukraine) }\end{array}$ & $\mathrm{RCT}$ & $\begin{array}{l}187 \text { (184 for } \\
\square \text { mITT popu- } \\
\text { lation) }\end{array}$ & $\begin{array}{l}\text { PD }(65 \%) \text {, stroke }(7 \%) \text {, ALS } \\
(6 \%), \text { medication-induced si- } \\
\text { alorrhea }(3 \%) \text {, adult cerebral } \\
\text { palsy }(2 \%) \text { and other disor- } \\
\text { ders }(16 \%)\end{array}$ & $\begin{array}{l}\text { Adults } \\
{[64(18-85)]}\end{array}$ & $\begin{array}{l}147 / 40 \\
(144 / 40 \text { for } \\
\square \text { mITT } \\
\text { population) }\end{array}$ \\
\hline $\begin{array}{l}\text { Tiigimäe- } \\
\text { Saar et al. } \\
(2018)\end{array}$ & Estonia & $\begin{array}{l}\text { Quasi-experi- } \\
\text { mental study }\end{array}$ & 38 & $\begin{array}{c}\text { PD (31\% with and } 34 \% \text { with- } \\
\text { out sialorrhea) }\end{array}$ & $\begin{array}{c}\text { Adults } \\
{[71(58-88)]}\end{array}$ & $22 / 16$ \\
\hline $\begin{array}{l}\text { Tiigimäe- } \\
\text { Saar et al. } \\
\quad(2017)\end{array}$ & Estonia & $\begin{array}{l}\text { Quasi-experi- } \\
\text { mental study }\end{array}$ & 20 & $\begin{array}{c}\text { PD }(60 \%), \text { ALS }(15 \%) ; \text { birth } \\
\text { hypoxia }(10 \%) \text {; atypical } \\
\text { headache }(10 \%) \text { and stroke } \\
(5 \%)\end{array}$ & $\begin{array}{l}\text { Adults and } \\
\text { children } \\
\text { [63(3-79)] }\end{array}$ & $12 / 8$ \\
\hline $\begin{array}{l}\text { Moller et al. } \\
(\text { (2015) }\end{array}$ & Denmark & $\begin{array}{l}\text { Quasi-experi- } \\
\text { mental study }\end{array}$ & 14 & $\mathrm{CP}$ & \begin{tabular}{|c|} 
Children $[9(5-$ \\
$16)]$ \\
\end{tabular} & $8 / 6$ \\
\hline $\begin{array}{l}\text { Wu et al. } \\
\text { (2011) }\end{array}$ & Taiwan & $\mathrm{RCT}$ & 20 & $\mathrm{CP}$ & $\begin{array}{l}\text { Children }[8(3- \\
16)]\end{array}$ & $9 / 11$ \\
\hline
\end{tabular}

ALS: Amyotrophic lateral sclerosis; CP: Cerebral Palsy; DB: double-blind; $\square$ mITT: modified Intention to Treat; OL: Open Label; PD: Parkinson's disease and RCT: Randomized controlled trial.

Table 2: Interventions and outcomes of included studies are summarized.

\begin{tabular}{|c|c|c|c|c|c|c|}
\hline Author & Intervention & Comparison & $\begin{array}{c}\text { Dose units per } \\
\text { submandibular/ } \\
\text { parotid gland } \\
\text { respectively }\end{array}$ & Outcomes & Follow-up time & Key findings \\
\hline \multirow[b]{2}{*}{$\begin{array}{c}\text { Stuart } \\
\text { Isaacson et } \\
\text { al. }(2020)\end{array}$} & $\begin{array}{c}\text { DB phase: BoNT-B } \\
\text { (Myobloc }(2) \text { 2500 U and } \\
\text { BoNT-B (Myobloc }()) \\
3500 \mathrm{U} ;\end{array}$ & $\begin{array}{l}\text { DB phase: Volume- } \\
\text { matched placebo. }\end{array}$ & $\begin{array}{l}2500 \text { U group: } \\
250 / 1000 \mathrm{U} ;\end{array}$ & \multirow[b]{2}{*}{$\begin{array}{l}\text { Dental Ca- } \\
\text { ries }\end{array}$} & $\begin{array}{l}\text { DB phase: } 13 \\
\text { Weeks; }\end{array}$ & \multirow{2}{*}{$\begin{array}{l}\text { Dental caries in DB phase } \\
\text { respectively: } 2500 \mathrm{U} \\
\text { group: } 8 \% ; 3500 \text { Uroup: } \\
5 \% \text {; placebo: } 3 \% \text { Dental } \\
\text { caries at OL phase Group } \\
\text {-cycle } 2: 29 \%(\mathrm{p}=0.504)\end{array}$} \\
\hline & $\begin{array}{l}\text { OL phase: BoNT-B } \\
\text { (Myobloc®) } 3500 \text { U } \\
\text { at first OL cycle (dose } \\
\text { adjustments allowed). } \\
\text { Bilateral injections into } \\
\text { parotid and subman- } \\
\text { dibular glands }\end{array}$ & OL phase: None. & $\begin{array}{l}\text { 3500 U group: } \\
250 / 1500 \mathrm{U}\end{array}$ & & $\begin{array}{l}\text { OL phase: every } \\
13 \text { weeks (maxi- } \\
\text { mum of } 4 \text { treat- } \\
\text { ment sessions } \\
\text { post-injection } \\
\text { periods) }\end{array}$ & \\
\hline $\begin{array}{c}\text { Tiigimäe- } \\
\text {-Saar et al. } \\
\quad(2018)\end{array}$ & $\begin{array}{c}\text { BoNT-A (Dysport } \mathbb{R} \text { ) } \\
\text { bilateral injections into } \\
\text { the parotid and subman- } \\
\text { dibular glands }\end{array}$ & $\begin{array}{l}\text { Participants' pre- and } \\
\text { post-injections sali- } \\
\text { vary composition and } \\
\text { cariogenic bacterial } \\
\text { counts in the inter- } \\
\text { vention group and } \\
\text { between intervention } \\
\text { and control groups. } \\
\end{array}$ & $\begin{array}{l}250 \mathrm{U} \text { (total } \\
\text { dose) }\end{array}$ & $\begin{array}{l}\text { Buffering ca- } \\
\text { pacity; oral } \\
\text { pH;SM and } \\
\text { LB salivary } \\
\text { levels }\end{array}$ & 4 weeks & $\begin{array}{c}\text { No statistically significant } \\
\text { change in oral } \mathrm{pH}(\mathrm{p}= \\
0.687)^{* *} \text { and SM CFU } \\
\text { count groups }(\mathrm{p}=0.206), \\
\text { but buffering capacity } \\
(\mathrm{p}=0.037) \text { and LB CFU } \\
\text { counts ( } \mathrm{p}=0.047) \text { were } \\
\text { increased }\end{array}$ \\
\hline $\begin{array}{l}\text { Tiigimäe- } \\
\text {-Saar } \text { et al. } \\
\quad(2017)\end{array}$ & $\begin{array}{l}\text { BoNT-A (Dysport@) } \\
\text { bilateral injections into } \\
\text { parotid and subman- } \\
\text { dibular glands }\end{array}$ & $\begin{array}{l}\text { Participants' pre- and } \\
\text { post-injections sali- } \\
\text { vary composition and } \\
\text { cariogenic bacterial } \\
\text { counts. No control } \\
\text { group. }\end{array}$ & $\begin{array}{l}\text { Weight-depen- } \\
\text { dent dose }{ }^{\alpha}\end{array}$ & $\begin{array}{c}\text { Buffering ca- } \\
\text { pacity; oral } \\
\text { pH;SM and } \\
\text { LB salivary } \\
\text { levels }\end{array}$ & 4 weeks & $\begin{array}{c}\text { No statistically significant } \\
\text { change in oral } \mathrm{pH}(\mathrm{p}= \\
0.494) \text {, buffering capacity } \\
(\mathrm{p}=0.082), \mathrm{SM}(\mathrm{p}=0.357) \\
\text { CFU count groups and } \\
\text { LB }(\mathrm{p}=0.094)\end{array}$ \\
\hline $\begin{array}{l}\text { Moller et } \\
\text { al. (2015) }\end{array}$ & $\begin{array}{l}\text { BoNT-A (Botox }{ }^{\circledR)} \\
\text { injections in six suc- } \\
\text { cessive increasing dose } \\
\text { series. Bilateral injec- } \\
\text { tions into parotid and } \\
\text { submandibular glands }\end{array}$ & $\begin{array}{l}\text { Participants' pre- } \\
\text { and post-injections } \\
\text { salivary composition } \\
\text { parameters }\end{array}$ & $\begin{array}{l}\text { Series A:10/0 U; } \\
\text { Series B:15/0 U; } \\
\text { Series C:20/0 U; } \\
\text { Series D:20/20 } \\
\text { U; Series } \\
\text { E:30/20 U; Se- } \\
\text { ries F: } 30 / 30 \text { U }\end{array}$ & $\begin{array}{l}\text { Dental Ca- } \\
\text { ries }\end{array}$ & 20 weeks & $\begin{array}{c}\text { No reports of dental } \\
\text { Caries }\end{array}$ \\
\hline $\begin{array}{c}\text { Wu et al. } \\
\text { (2011) }\end{array}$ & $\begin{array}{l}\left.\text { BoNT-A (Botox }{ }^{\circledR}\right) \\
\text { bilateral injections into } \\
\text { parotid and subman- } \\
\text { dibular glands }\end{array}$ & $\begin{array}{c}\text { Normal saline placebo } \\
\text { injections }\end{array}$ & $\begin{array}{l}\text { Weight-depen- } \\
\text { dent dose } e^{\varphi}\end{array}$ & $\begin{array}{c}\text { Oral pH;SM } \\
\text { and LB sali- } \\
\text { vary levels }\end{array}$ & 12 weeks & $\begin{array}{c}\text { No statistically significant } \\
\text { change in oral pH (p= } \\
\text { 0.398) and LB and SM } \\
\text { CFU count groups (no } \\
\text { data available) }\end{array}$ \\
\hline
\end{tabular}

Intraglandular Botulinum neurotoxin (BoNT); Colony Forming Unit (CFU); Double-Blind (DB); Lactobacilli (LB); Open Label (OL) ;Streptococcus mutans (SM); Unit (U); 'Follow-up 1, 2, and 3 months for others outcomes but only 1 month for salivary tests; ** Wilcoxon test. Results different from those published in the article. 
- Carious lesions

In the double-blind (DB) phase of the multicenter RCT by Stuart Isaacson (2), carious lesions development were observed in $8 \%$ of the patients of the $2500 \mathrm{U}$ BoNT group, $5 \%$ of the patients of the $3500 \mathrm{U}$ BoNT group, and in $3 \%$ of the patients of the placebo group. From these data, we were able to calculate the relative risk of developing new carious lesions (compared to placebo) of 2.4 (95\% confidence interval $[\mathrm{CI}]=0.48-11.80)$ for the $2500 \mathrm{U}$ group, and $1.4(95 \% \mathrm{CI}=0.24-8.12)$ for the 3500 $\mathrm{U}$ group. The results of the Chi-square test performed by us did not show statistically significant differences in group comparison $(p=0.504)$. Carious lesions were also assessed in the open-label study of Moller et al. (16), which reported no cases of tooth decay.

- Salivary buffering capacity

The quasi-experimental studies of Tiigimäe-Saar et al. $(22,23)$ found different results concerning the changes in buffering capacity. For the analysis carried out in 2017 (23), no statistically significant change was observed. By contrast, the 2018 study reported significantly increased buffering capacity one month after BoNT injections (22). - Oral $\mathrm{pH}$

Wu et al. (21) did not observe significant differences in participants' oral $\mathrm{pH}$ before and after BoNT-A injections between the active and control groups. There were also no statistically significant differences regarding salivary $\mathrm{pH}$ in the two other quasiexperimental studies $(22,23)$ that also analyzed this variable.

- S. mutans and Lactobacilli salivary counts

The RCT by Wu et al. (21) did not provide any data - either in the form of primary data or effect size measures - related to the cariogenic bacterial count presenting only the hypothesis tests results (in the form of $p$-value) for the comparison between the baseline and the postintervention period. The authors reported no statistically significant changes in S. mutans and Lactobacilli colony-forming units (CFU) counts. The studies of Tiigimae-Saar did not find statistically significant differences in S. mutans CFU counts either $(22,23)$. However, the 2018 study found that Lactobacilli CFU counts were significantly increased one month after BoNT injections (22).

- Risk of bias of individual studies

Fig. 2 displays the risk of bias classification for randomized studies, while Fig. 3 and Fig. 4 depict such classification for non-randomized studies.

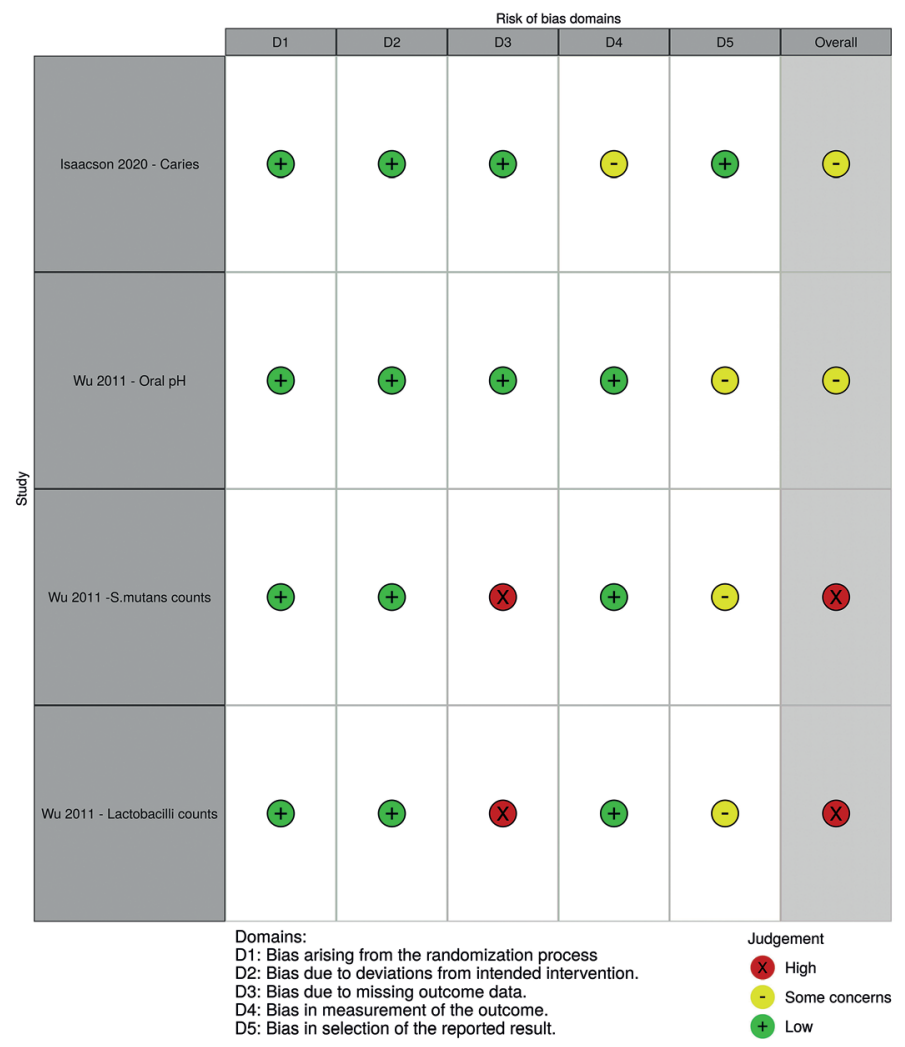

Fig. 2: Risk of bias for randomized studies (by robvis tool). 


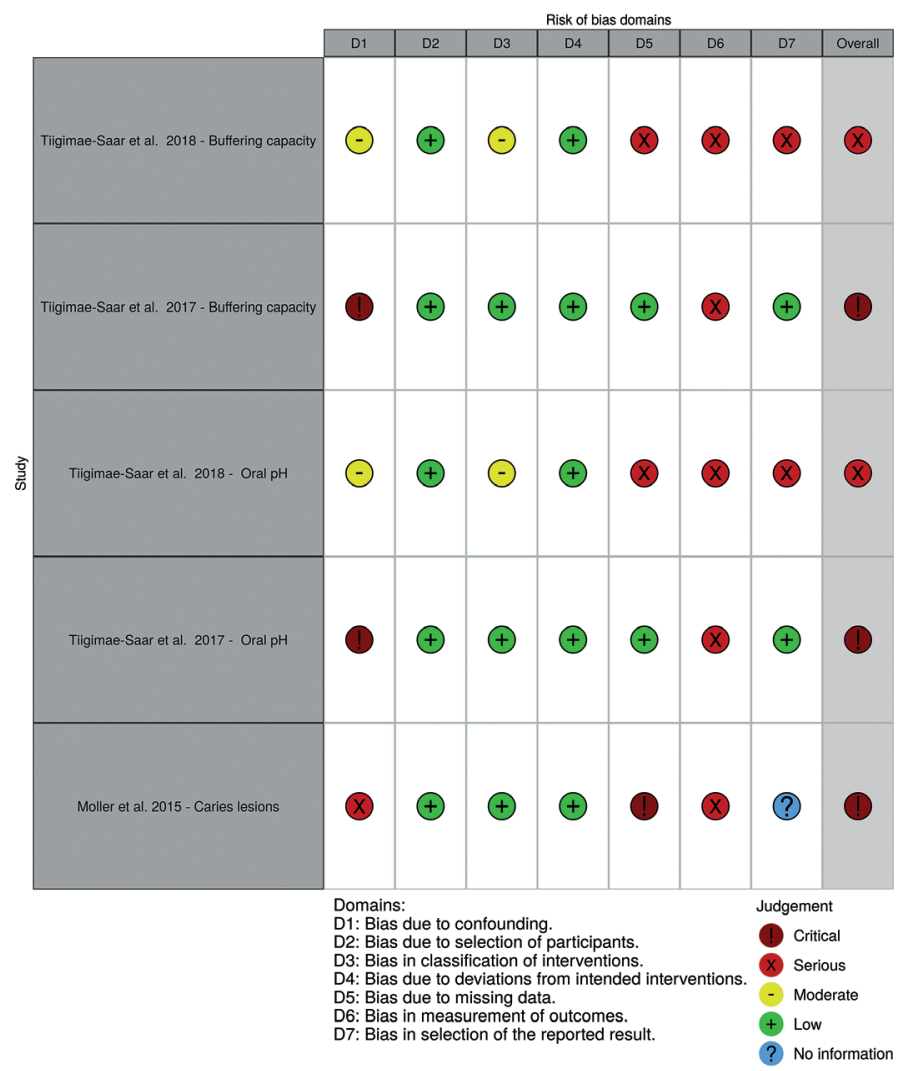

Fig. 3: Risk of bias for non-randomized studies for saliva composition and caries (by robvis tool).

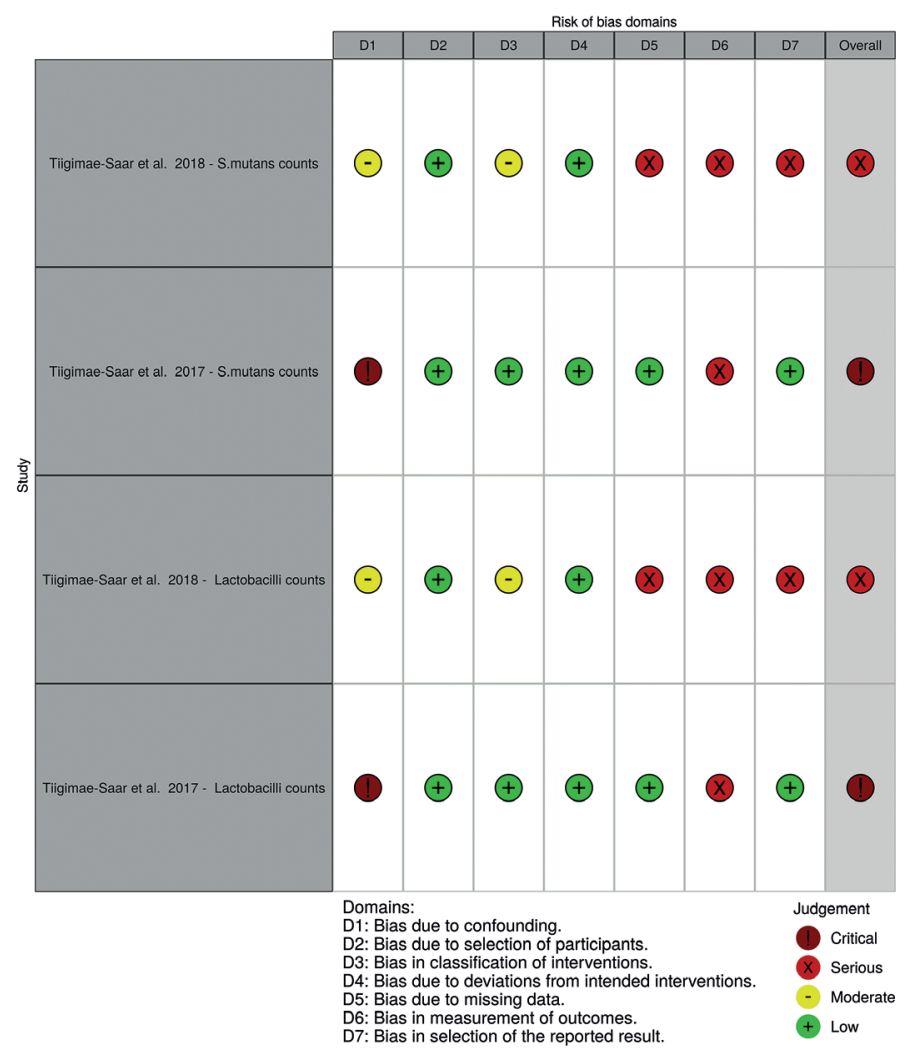

Fig. 4: Risk of bias for non-randomized studies for cariogenic bacteria counts (by robvis tool). 
The multicenter randomized trial (2) was overall classified as having "some concerns" on its risk of bias, particularly due to concerns in outcome measurement. This study protocol mentions that four radiographic bitewings were to be taken and that Dental Adverse Event (DAE) criteria were followed as defined in the protocol. However, it is not clear if the independent dentists were calibrated and how the oral examination was performed, how carious lesions were diagnosed, or how were dental caries was defined. Therefore, doubts remain on whether incipient lesions could have been unreported due to the adopted diagnosis methods.

The RCT published by Wu et al. (21) was overall judged to be of "some concerns" in relation to oral $\mathrm{pH}$. We have not found any publicly available research protocol or pre-specified analysis plan. Regarding cariogenic bacteria counts, the overall risk of bias was considered high, as no protocol was found and the study only provides the corresponding $p$-value.

As for the non-randomized studies, the study by Moller et al. (16) was classified as having a critical risk of bias. Which is explained by the absence of dental caries definition, the possibility of confounding due to the performance of extra oral exams and oral hygiene instructions, and the absence of a control group.

The 2017 study by Tiigimäe-Saar et al. (23) was judged to have an overall critical risk of bias for all outcomes. Not only there was no control group, but also there was a serious possibility for confounding. In fact, participants were very heterogeneous regarding their underlying diseases and medication use, with no described approach for adjustment or control of confounding variables. In addition, the outcome measurement involved subjective judgments by the evaluator.

The 2018 study by Tiigimäe-Saar et al. (22) was classified as having a serious risk of bias. Although the authors presented results for two control groups, both control groups were not comparable as they did not have hypersalivation (one of the control groups consisted of healthy individuals). There is also a risk of selection bias (namely, indication bias), since only subjects with drooling received BoNT injections. Regarding outcomes measurement, as with the 2017 study (23), subjective measurement methods were used for all outcomes.

\section{Discussion}

Overall, in this systematic review, we did not find any primary study reporting associations between BoNT use and caries development. Regarding the remaining outcomes, only one study found statistically significant differences in salivary composition, particularly in buffer capacity and Lactobacilli counts. Therefore, existing evidence suggests that BoNT are safe to use in patients with drooling. However, care should be taken when interpreting these results, as all included studies had at least "some concerns" regarding their risk of bias.

None of the two studies $(2,16)$ assessing carious lesions found BoNT to be associated with caries development. In fact, Moller et al. (16) did not report any dental caries, which might be a consequence of the extraoral examinations and hygiene instructions provided during the studied period. Nevertheless, neither of these two studies $(2,16)$ presented the definition used for caries diagnosis. Regarding buffer capacity, despite expectations that the salivary buffer capacity would be reduced and hinder the neutralization process of the oral environment (further reducing the oral $\mathrm{pH}$ ), Tiigimäe-Saar observed an increased stimulated saliva's buffer capacity after BoNT injections (22) pointing to saliva's ability to resist changes in the oral environment balance when challenged. Such differences were not found in the other studies assessing buffering capacity (23) and oral $\mathrm{pH}$ (21-23). The differences between studies may be explained by the applied measurement methods (measuring of saliva in different states and lack of measurement concealment in the two $(22,23)$ quasi-experimental studies) and by the intervention characteristics such as dosage used, various types of underlying diseases and inadequate allocation of participants into groups. The Tiigimäe-Saar 2018 study (22) also found a significant increase in Lactobacilli counts. Lactobacilli are more acidic and a drop in salivary $\mathrm{pH}$ may be a factor that favors their increase (24). However, the reduction in the unstimulated saliva's pH at 2018 study (22) was not statistically significant, leaving doubts about whether the $\mathrm{pH}$ reduction contributed to a more accentuated growth of Lactobacilli. Other factors that may explain this Lactobacilli increase concern (i) the use, in this study (22), of a pre-established dose of BoNT (while the other two studies applied a weight-based dosage), (ii) and differences in information or control of the use of mouthwashes and oral antiseptics (Lactobacilli have bigger resistance to bacteria-reducing substances, such as chlorhexidine, and are more abundant in areas that are difficult to clean (25)).

This systematic review presents some limitations, mostly related to the included primary studies. Firstly, there was limited evidence for some outcomes - including caries risk and salivary osmolarity -, which were not assessed by all primary studies. In addition, the methods of outcomes assessment may also be a matter of concern - (i) pH, buffer capacity and bacterial counts were subjectively assessed in both Tiigimäe-Saar studies $(22,23)$, and (ii) it is not clear whether saliva samples are appropriate for evaluating the microbiology of oral diseases. In this respect, the literature is controversial, with some studies claiming that such samples are appropriate $(26,27)$ and others not $(28,29)$. There are also important concerns related to primary studies' sample sizes. In fact, only the multicenter RCT (2) mentioned 
having performed a sample size calculation. Therefore, the included studies were probably underpowered to detect relevant differences for all endpoints of this review. Lack of control for confounding factors should also be taken into account. One of such factors concerns participants' underlying diseases. In Parkinson' disease (PD), previous studies have found drooling to be more frequent in patients of older age, with more severe presentations (30), and with longer disease duration (22). The amount of saliva produced also appears to mirror the leading PD symptom (22), being akinesia-rigidity the most frequent disease subtype among PD patients with sialorrhea, and tremor the most frequent subtype among PD patients without sialorrhea (22). On the other hand, in patients with cerebral palsy, their neuromotor abnormality type may also affect the salivary parameters - patients with spastic palsy appear to have lower saliva flow rate, as well as lower $\mathrm{pH}$ and buffer capacity (31). Another key confounding factor concerns the potential influence of medication. The use of medications that interfere with drooling was not allowed in some of the studies $(16,22,23)$ that were included in this systematic review. However, the effects that many drugs have on saliva may not yet be known. As the multicenter trial was the only study in which randomization was performed (2), this is the only study for which samples may be comparable regarding medication use.

Regarding BoNT injection sites and doses, the studies varied widely, which may have influenced the observed results as well. For example, as parotid secretions predominate in the stimulated state (32) and produce a watery saliva $(33,34)$, higher BoNT injections doses into those glands could, along with increased salivary osmolality and reduced buffering capacity, reduce the removal of food debris (as there would be lower water content in saliva) and increase caries risk. On the other hand, submandibular gland secretions predominate in the in the unstimulated state (32) with a lower concentration of bicarbonate (35) and, when salivary flow is lower, acid by-products may remain in longer contact with oral structures (32) and increasing caries risk.

Finally, we did not analyze all oral changes that can potentially result from BoNT treatment. For example, we were not able to assess the effect of BoNT in the salivary concentration of proteins and electrolytes, or in the counts of bacteria other than S. mutans and Lactobacilli (the latter issue can be particularly relevant as dental caries is a dysbiosis, with S. mutans and Lactobacilli representing a small percentage of mouth bacteria (28)). Despite these limitations, this systematic review has important strengths. In order to minimize the risk of selection bias and the impact of publication bias, we used a comprehensive query, and searched in four bibliographic databases, with electronic searches being complemented by manual search methods. Primary studies' selection and quality assessment was performed according to Cochrane recommended practices. Following data extraction, we contacted the authors of primary studies to obtain missing information. Finally, to the best of our knowledge, this is the first systematic review on the topic, synthesizing and evaluating the quality of the existing evidence.

In conclusion, this systematic review has not found evidence that, in patients with drooling, BoNT injections associate with caries development or disturbances in oral $\mathrm{pH}$, buffer capacity and cariogenic bacterial counts. However, we cannot yet affirm that BoNT is completely safe, as included primary studies had important limitations and differences in their methodologies. Therefore, future studies - preferentially RCT - should be conducted, adopting standardized procedures and adequately controlling for confounding. On Supplementl (http:// www.medicinaoral.com/medoralfree01/aop/24101 supplement2.pdf), we list a series of clinical and methodological recommendations for future studies assessing the effect of BoNT in patients with drooling.

\section{References}

1. Morgante F, Bavikatte G, Anwar F, Mohamed B. The burden of sialorrhoea in chronic neurological conditions: current treatment options and the role of incobotulinumtoxinA (Xeomin $($ ) $)$. Ther Adv Neurol Disord. 2019;12:1-21.

2. Isaacson SH, Ondo W, Jackson CE, Trosch RM, Molho E, Pagan F, et al. Safety and Efficacy of RimabotulinumtoxinB for Treatment of Sialorrhea in Adults. JAMA Neurol. 2020;77:E1-9.

3. Varley LP, Denieffe S, O'Gorman C, Murphy A, Gooney M. A systematic review of noninvasive and invasive sialorrhoea management. J Clin Nurs. 2019;28:4190-206.

4. Abboud WA, Nadel S, Hassin-Baer S, Arad A, Dobriyan A, Yahalom R. Ultrasound-Guided Botulinum Toxin Injections into the Salivary Glands for the Treatment of Drooling. Isr Med Assoc J. 2019;2:116-9.

5. Taib BG, Williams SP, Sood S, Ung K, Nixon PP, Sharma R. Treatment of sialorrhoea with repeated ultrasound-guided injections of botulinum toxin A into the parotid and submandibular glands. Br J Oral Maxillofac Surg. 2019;57:442-8.

6. Jost WH, Friedman A, Michel O, Oehlwein C, Slawek J, Bogucki A, et al. Long-term incobotulinumtoxinA treatment for chronic sialorrhea: Efficacy and safety over 64 weeks. Parkinsonism Relat Disord. 2020;70:23-30.

7. Jost WH, Friedman A, Michel O, Oehlwein C, Slawek J, Bogucki A, et al. SIAXI. Neurology. 2019;92:e1982-91.

8. Paracka L, Kollewe K, Klietz M, Petri S, Dressler D. IncobotulinumtoxinA for hypersalivation in patients with amyotrophic lateral sclerosis: an open-label single-centre study. J Neural Transm. 2019;126:1341-5.

9. Lamb R, Rohrer JD, Lees AJ, Morris HR. Progressive Supranuclear Palsy and Corticobasal Degeneration: Pathophysiology and Treatment Options. Curr Treat Options Neurol. 2016;18:42-59.

10. Jackson CE, Gronseth G, Rosenfeld J, Barohn RJ, Dubinsky $\mathrm{R}$, Simpson CB, et al. Randomized double-blind study of botulinum toxin type B for sialorrhea in als patients. Muscle Nerve. 2009;39:137-43.

11. Ondo WG, Hunter C, Moore W. A double-blind placebo-controlled trial of botulinum toxin B for sialorrhea in Parkinson's disease. Neurology. 2004;62:37-40.

12. Porte M, Chaléat-Valayer E, Patte K, D'Anjou M-C, Boulay C, Laffont I. Relevance of intraglandular injections of Botulinum toxin 
for the treatment of sialorrhea in children with cerebral palsy: A review. Eur J Paediatr Neurol. 2014;18:649-57.

13. Gutierrez G, Siqueira V, Loyola-Rodriguez J, Diniz M, Guare R, Ferreira A, et al. Effects of treatments for drooling on caries risk in children and adolescents with cerebral palsy. Med Oral Patol Oral y Cir Bucal. 2019;24:e204-10.

14. Pedersen AML, Sørensen CE, Proctor GB, Carpenter GH, Ekström J. Salivary secretion in health and disease. J Oral Rehabil. 2018;45:730-46.

15. Mese H, Matsuo R. Salivary secretion, taste and hyposalivation. J Oral Rehabil. 2007;34:711-23.

16. Møller E, Pedersen S, Vinicoff P, Bardow A, Lykkeaa J, Svendsen $\mathrm{P}$, et al. Onabotulinumtoxin A Treatment of Drooling in Children with Cerebral Palsy: A Prospective, Longitudinal Open-Label Study. Toxins (Basel). 2015;7:2481-93.

17. Møller E, Daugaard D, Holm O, Winge K, Bardow A, Lykkeaa $\mathrm{J}$, et al. Repeated treatments of drooling with botulinum toxin B in neurology. Acta Neurol Scand. 2015;131:51-7.

18. Moher D, Liberati A, Tetzlaff J, Altman DG. Preferred reporting items for systematic reviews and meta-analyses: The PRISMA statement. Int J Surg. 2010;8:336-41.

19. Sterne JAC, Savović J, Page MJ, Elbers RG, Blencowe NS, Boutron I, et al. RoB 2: a revised tool for assessing risk of bias in randomised trials. BMJ. 2019;366:14898.

20. Sterne JA, Hernán MA, Reeves BC, Savović J, Berkman ND, Viswanathan M, et al. ROBINS-I: a tool for assessing risk of bias in non-randomised studies of interventions. BMJ. 2016;355:i4919-26. 21. Wu KPH, Ke JY, Chen CY, Chen CL, Chou MY, Pei YC. Botulinum Toxin Type A on Oral Health in Treating Sialorrhea in Children With Cerebral Palsy: A Randomized, Double-Blind, Placebo-Controlled Study. J Child Neurol. 2011;26:838-43.

22. Tiigimäe-Saar J, Tamme T, Rosenthal M, Kadastik-Eerme L, Taba P. Saliva changes in Parkinson's disease patients after injection of Botulinum neurotoxin type A. Neurol Sci. 2018;39:871-7.

23. Tiigimäe-Saar J, Taba P, Tamme T. Does Botulinum neurotoxin type A treatment for sialorrhea change oral health? Clin Oral Investig. 2017;21:795-800.

24. Müller VJ, Belibasakis GN, Bosshard PP, Wiedemeier DB, Bichsel D, Rücker M, et al. Change of saliva composition with radiotherapy. Arch Oral Biol. 2019;106:104480-8.

25. Mummolo S, Marchetti E, Giuca MR, Gallusi G, Tecco S, Gatto $\mathrm{R}$, et al. In-office bacteria test for a microbial monitoring during the conventional and self-ligating orthodontic treatment. Head Face Med. 2013;9:1-8

26. Zhang L, Sun T, Zhu P, Sun Z, Li S, Li F, et al. Quantitative Analysis of Salivary Oral Bacteria Associated with Severe Early
Childhood Caries and Construction of Caries Assessment Model. Sci Rep. 2020;10:6365-73.

27. Jiang S, Gao X, Jin L, Lo E. Salivary Microbiome Diversity in Caries-Free and Caries-Affected Children. Int J Mol Sci. 2016;17:1978-91.

28. Simón-Soro A, Mira A. Solving the etiology of dental caries. Trends Microbiol. 2015;23:76-82.

29. Simón-Soro Á, Tomás I, Cabrera-Rubio R, Catalan MD, Nyvad B, Mira A. Microbial Geography of the Oral Cavity. J Dent Res. 2013;92:616-21

30. Goetz CG, Tilley BC, Shaftman SR, Stebbins GT, Fahn S, Martinez-Martin P, et al. Movement Disorder Society-sponsored revision of the Unified Parkinson's Disease Rating Scale (MDS-UPDRS): Scale presentation and clinimetric testing results. Mov Disord. 2008;23:2129-70.

31. Santos MT, Guaré R, Leite M, Ferreira MC, Nicolau J. Does the neuromotor abnormality type affect the salivary parameters in individuals with cerebral palsy? J Oral Pathol Med. 2010;39:770-4.

32. Humphrey SP, Williamson RT. A review of saliva: Normal composition, flow, and function. J Prosthet Dent. 2001;85:162-9.

33. Holmberg KV, Hoffman MP. Anatomy, Biogenesis and Regeneration of Salivary Glands. In: Monographs in Oral Science. 2014;24:1-13. 34. Jost WH, Bäumer T, Laskawi R, Slawek J, Spittau B, Steffen A, et al. Therapy of Sialorrhea with Botulinum Neurotoxin. Neurol Ther. 2019;8:273-88.

35. Ferraz dos Santos B, Dabbagh B, Daniel SJ, Schwartz S. Association of onabotulinum toxin A treatment with salivary $\mathrm{pH}$ and dental caries of neurologically impaired children with sialorrhea. Int J Paediatr Dent. 2016;26:45-51

\section{Funding}

None declared.

\section{Conflict of interest}

The authors declared no conflicts of interest with respect to the research, authorship, and/or publication of this article.

Ethics

Udam sae coneculpa eariost, accae. Nam sunt, sent, num ut mo moluptatem resecta sunt.

\section{Authors contributions}

LBCC developed the study design in cooperation with the BSP. LBCC wrote the manuscript draft. MBB has been a contributor to selection and extraction of data. The manuscript was reviewed by the third (BSP) and fourth (SCL) authors. 